\title{
KEJADIAN DBDDI KELURAHAN MANISREJO KECAMATAN TAMAN KOTA MADIUN TAHUN 2015
}

Firda Lutfi Pangresti,TuhuPinardi,HeryKoesmantoro

\section{ABSTRACT}

Manisrejo village incidence of dengue fever is the highest among the City of Madiun. The number of cases of dengue hemorrhagic fever in that village was as many as 84 cases in 2010-2014. This study aims to find out about the incidence of dengue fever. By measuring behavioral factors, assess physical factors, calculating factor-free numbers larva, evaluate PSN (mosquito nest eradication), evaluates health services, measuring the socio-economic factors, and to describe the incidence of dengue fever.

This type of research is a descriptive study. Populations were all cases of dengue fever in the village Manisrejo District of the City of Madiun. The sample is purposive sampling counted 84 cases and the controls.

The results generated from the calculation of questionnaires and observation done. It is known that most of the respondents behavior is bad namely $87.8 \%$, physical factors such as temperature and humidity most of the houses of the respondents have optimum temperature and humidity which is a mosquito breeding sites by $83.67 \%$. Village ofManisrejois still not free from larvae, this is because free larva houseswere still below $95 \%$, the mosquito eradication is bad that is equal to $59.2 \%$, patients with dengue fever in the village Manisrejo utilize health services and are willing to seek treatment when exposed to pain, patients with dengue fever at most households were not poor $84,7 \%$.

It is recommended to the citizens in order to improve the attitudes and actions of mosquito control, as well as the mobilization of mosquito eradication movement cadres in particular for monitoring larvae, as well as public attention to environmental conditions such as opening a window or vent, this can help to regulate the temperature and humidity.

Keywords : Dengue hemorrhagic fever, dengue fever incidence study.

\section{PENDAHULUAN}

Pencegahan penyakit demam berdarah sebenarnya ditunjukkan pada pencegahan virus Dengue yang dibawa oleh nyamuk Aedes aegypti. Melakukan pencegahan ini meliputi menjaga lingkungan dan menjaga daya tahan tubuh ( N Frida, 2008).

Berdasarkan Diklat Jabatan Fungsional Entomolog Kesehatan Di BBPK Ciloto Tahun 2008 , gerakan pemberantasan nyamuk (PSN) atau yang dikenal dengan gerakan 3M (menutup, menguras, dan mengubur) tempat berkembangbiaknya nyamuk adalah seluruh kegiatan masyarakat bersama pemerintah yang dilakukan secara berkesinambungan untuk mencegah dan menanggulangi penyakit demam berdarah.

Menurut Pusat Promosi Kesehatan Departemen Kesehatan RI (2006). Perilaku manusia dipengaruhi oleh resultansi dari berbagai faktor baik internal maupun eksternal (lingkungan). Perilaku manusia sebenarnya merupakan refleksi dari berbagai gejala kejiwaan seperti pengetahuan, persepsi, sikap, keyakinan dan lain-lain.

Penyakit Demam Berdarah Dengue (DBD) atau yang disebut Dengue
Hemorrhagic Fever (DHF), adalah penyakit yang disebabkan oleh virus dengue yang tergolong arbovirus dan ditularkan melalui gigitan nyamuk Aedes aegypti dan Aedes albopictus. Penyakit ini dapat menyebabkan gangguan pada pembuluh darah kapiler dan pada sistem pembekuan darah sehingga mengakibatkan perdarahan-perdarahan. Penyakit ini banyak ditemukan di daerah tropis seperti Asia Tenggara, India, Brazil, Amerika termasuk di seluruh pelosok Indonesia, kecuali di tempattempat dengan ketinggian lebih dari 1000 meter di atas permukaan air laut (Sukmawati Indah, 2008).

Berdasarkan Direktorat Jenderal Pengendalian Penyakit dan penyehatan lingkungan Kementerian Kesehatan Republik Indonesia Angka kesakitan demam berdarah tahun 2013 tercatat 45,85 per 100.000 penduduk (112.511 kasus) dengan angka kematian sebesar 0,77 \% (871 kematian). Sedangkan pada tahun 2014 ini sampai awal bulan April tercatat angka kesakitan demam berdarah Dengue sebesar 5,17 per 100.000 penduduk (13.031 kasus) dengan angka kematian sebesar 0,84\% (110 kematian). 
Berdasarkan Buku Profil Kesehatan Propinsi Jawa Timur Tahun 2012 yaitu penyakit demam berdarah merupakan salah satu penyakit yang menjadi masalah kesehatan masyarakat dan endemis di hampir seluruh kabupaten/kota di Jawa Timur. Demam berdarah Dengue juga sudah menjadi masalah yang rutin dihadapi pada setiap musim hujan. Angka kesakitan di Jawa Timur cukup tinggi, meskipun jumlah kematian yang terjadi dapat ditekan.

Berdasakan laporan data infeksi virus Dengue kota Madiun angka kesakitan demam berdarah Kota Madiun ada pada setiap tahunnya, dari tahun 2010 hingga tahun 2014, terdapat daerah endemis di kota Madiun, dikatakan endemis apabila terdapat kejadian penyakit selama 3 tahun berturut-turut walaupun angka kesakitan demam berdarah Dengue tersebut kecil, salah satu daerah endemis di kota Madiun adalah daerah Manisrejo, jumlah penduduk untuk daerah Manisrejo yaitu 16.279 jiwa, dengan jumlah kepala keluarga 4.704 kepala keluarga. Dari tahun 2010 hingga 2014 terdapat angka kesakitan demam berdarah, angka kesakitan demam berdarah Dengue paling tinggi pada tahun 2013 dan tahun 2014 yaitu sebanyak 24 jiwa dan angka kesakitan demam berdarah Dengue paling rendah pada tahun 2011 yaitu sebanyak 2 jiwa (Dinas Kesehatan Kota Madiun Tahun 2010-2014).

Berdasarkan uraian di atas maka peneliti merasa penting untuk dilakukan penelitian mengenai Studi Tentang Faktor Kejadian Demam Berdarah Dengan Pendekatan Sistem Kewaspadaan Dini Kesehatan Lingkungan Di Wilayah Kelurahan Manisrejo Kecamatan Taman Kota Madiun Tahun 2015.

\section{Tujuan}

Penelitian: mendeskripsikan kejadian DBD di Kelurahan Manisrejo, berdasarkan faktor Fisik Suhu dan Kelembaban, Faktor Perilaku Upaya PSN, dan Faktor Sosial Ekonomi masyarakat.

\section{METODE PENELITIAN}

Jenis penelitian yang digunakan adalah penelitian deskriptif. Penelitian Deskriptif adalah suatu penelitian yang dilakukan dengan tujuan utama untuk membuat gambaran atau deskriptif tentang suatu keadaan secara objektif, yaitu menggambarkan kejadian demam berdarah dengan fakrtor-faktor yang diteliti yaitu factor pemberantasan sarang nyamuk, factor perilaku terhadap kejadian demam berdarah, factor kepadatan jentik terhadap kejadian demam berdarah, factor Fisik terhadap kejadian demam berdarah, factor pelayanan kesehatan terhadap kejadian demam berdarah, factor social ekonomi masyarakat, kejadian demam berdarah.

Metode Pengambilan sample adalah Purposive Sampling, yaitu didasarkan pada pertimbangan/ criteria peneliti sesuai maksud dan tujuan (Amin Isman,dkk). Kriteria besar sampel yang diambil yaitu penderita penyakit demam berdarah, dan masyarakat yang mempunyai KK miskin, dengan social ekonomi yang rendah.

Wawancara dilakukan terhadap responden untuk mendapatkan data tentang pengetahuan, sikap, tindakan serta karakteristik individu yaitu pendidikan dan pekerjaan yang berkaitan dengan kejadian demam berdarah.

Observasi dilakukan untuk mengetahui tindakan responden, pelayanan kesehatan, kepadatan jentik, dan pemberantasan sarang nyamuk yang dinilai dengan check list

Dalam penelitian ini data yang dihasilkan diuraikan dalam bentuk table untuk menggambarkan keadaan yang sebenarnya kemudian data dianalisis dengan membandingkan angka range, angka efektifitas, serta dengan analisis system kewaspadaan dini berdasarkan tren penyakit demam beradarah Dengue.

\section{HASIL PENELITIAN DAN \\ PEMBAHASAN}

1. Kejadian DBD dan Faktor Perilaku

TABEL 1: DISTRIBUSI PERILAKU DAN KEJADIAN PENYAKIT DEMAM BERDARAH DENGUE DI KELURAHAN MANISREJO TAHUN 2015

\begin{tabular}{|c|c|c|c|}
\hline \multirow{2}{*}{ Kategori Perilaku } & \multicolumn{2}{|c|}{$\begin{array}{c}\text { Kejadian Penyakit de- } \\
\text { mam Berdarah Dengue }\end{array}$} & \multirow{2}{*}{ Jumlah } \\
\cline { 2 - 3 } & Sakit & TidakSakit & \\
\hline \multirow{2}{*}{ Baik } & 7 & 5 & 12 \\
& $(7,15 \%)$ & $(5,1 \%)$ & $(12,25 \%)$ \\
\hline \multirow{2}{*}{ Buruk } & 81 & 5 & 86 \\
& $(82,65 \%)$ & $(5,1 \%)$ & $\mathbf{9 8}(\mathbf{1 0 0} \%)$ \\
\hline
\end{tabular}



Berdasarkan data hasilsurvey
perilaku dengan kejadian demam berdarah dengue dinyatakan kategori perilaku buruk dengan yang sakit yaitu 81 orang dengan presentase $82,65 \%$ dan yang tidak sakit yaitu 5 orang dengan presentase 5,1\%, jumlah presentase kategori perilaku buruk yaitu $87,75 \%$. Sementara kategori perilaku baik dengan yang sakit yaitu 7 orang dengan presentase $7,15 \%$ dan yang tidak sakit 5 orang dengan presentase $5,1 \%$, jumlah presentase kategori perilaku baik yaitu 12,25\%. Dari data table menunjukkan bahwa perilaku responden yang terkena sakit cenderung buruk, hal ini membuktikan pengetahuan dari responden berpengaruh terhadap terjadinya penyakit demam berdarah Dengue. Perilaku dipengaruhi oleh pengetahuan, sikap dan tindakan, hal ini membuktikan informasi tentang penyakit demam berdarah Dengue kurang, dan perlu adanya penyuluhan mengenai kesehatan.
Penyuluhan kesehatan adalah kegiatan pendidikan yang dilakukan dengan cara menyebarkan pesan, menanamkan keyakinan, sehingga masyarakat tidak saja sadar, tahu dan mengerti, tetapi juga mau dan bias melakukan suatu anjuran yang ada hubungannya dengan kesehatan. Pendidikan kesehatan tidak dapat diberikan kepada seseorang oleh orang lain, bukan seperangkat prosedur yang harus dilaksanakan atau suatu produk yang harus dicapai, tetapi sesungguhnya merupakan suatu proses perkembangan yang berubah secara dinamis, yang di dalamnya seseorang menerima atau menolak informasi, sikap, maupun praktek baru, yang berhubungan dengan tujuan hidup sehat (Suwarono Edi, 2010).

2. Kejadian DBD dan Faktor Suhu dan kelembaban

TABEL 2: DISTRIBUSI RUMAH RESPONDEN BERDASARKAN SUHU DAN KELEMBABAN DAN KEJADIAN DEMAM BERDARAH DENGUE

\begin{tabular}{|c|c|c|c|}
\hline $\begin{array}{c}\text { Suhu dan } \\
\text { Kelembaban }\end{array}$ & \multicolumn{2}{|c|}{ Kejadian Demam Berdarah Dengue } & \multirow{2}{*}{ Jumlah } \\
\cline { 2 - 3 } & Sakit & Tidak Sakit & \\
\hline Optimum & 72 & 10 & 82 \\
& $(73,47 \%)$ & $(10,2 \%)$ & $(83,67 \%)$ \\
\hline \multirow{2}{*}{ Tidak optimum } & 16 & & 16 \\
& $(16,33 \%)$ & $(16,33 \%)$ \\
\hline \multicolumn{2}{|r|}{ Total } & & $\mathbf{9 8}(\mathbf{1 0 0 \%})$ \\
\hline
\end{tabular}

Sumber: Data Hasil Survey di Kelurahan Manisrejo Kec. Taman Bulan Maret Tahun 2015

Berdasarkan data hasilsurvey suhu dan kelembaban dengan kejadian demam berdarah dengue dinyatakan kategori suhu dan kelembaban optimum dengan yang sakit yaitu 72 orang dengan presentase $73,47 \%$ dan yang tidak sakit yaitu 10 orang dengan presentase $10,2 \%$, jumlah presentase kategori suhu dan kelembaban optimum yaitu $83,67 \%$. Sementara kategori suhu dan kelembaban optimum dengan yang sakit yaitu 16 orang dengan presentase $16,33 \%$ dan yang tidak sakit 0 orang dengan presentase kategori suhu dan kelembaban tidak optimum yaitu $16,33 \%$. Dari data tabel hubungan antara suhu dan kelembaban dengan kejadian penyakit demam berdarah Dengue, masih banyak rumah responden yang dinyatakan tidak optimum, 82 rumah penderita yang memiliki suhu dan kelembaban tidak optimum, sementara itu kurangnya pencahayaan dan cahaya matahari yang kurang masuk dalam ruangan, menybabkan menjadi tempat berkembangbiakan nyamuk. Metabolismenya menurun atau bahkan terhenti bila suhunya turun sampai di bawah suhu kritis $45^{\circ} \mathrm{C}$. Pada suhu yang lebih tinggi dari $35^{\circ} \mathrm{C}$ juga mengalami perubahan dalam arti lebih lambatnya proses-proses fisiologis, rata-rata suhu optimum untuk pertumbuhan nyamuk adalah $25-30^{\circ} \mathrm{C}$. Suhu udara mempengaruhi perkembangan virus dalam tubuh nyamuk, tingkat menggigit, istirahat dan perilaku kawin, penyebaran dan durasi siklus gonotrophik (Widya Hary Cahyati, 2006).

Kelembaban udara menentukan daya hidup nyamuk, yaitu menentukan daya tahan trachea yang merupakan alat pernafasan nyamuk (Rini Hidayati, 2008). Angka kelembaban di Indonesia bias 
mencapai $85 \%$. Hal ini disebabkan Indonesia merupakan Negara kepulauan yang lautannya lebih luas dari pada daratan, sehingga udara lebih banyak mengandung air. Rata-rata kelembaban untuk pertumbuhan nyamuk adalah 6190\% (Thomas Suroso, 2000). Sistem pernafasan nyamuk menggunakan pipa udara (trackea) dengan lubang-lubang pada dinding tubuh nyamuk (spiracle).

3. Kejadian DBD dan Faktor Upaya PSN.

Angka bebas jentik 92,86\%, diperoleh dari perhitungan jumlah rumah yang diperiksa dikurangi jumlah rumah yang positif jentik dibagi jumlah total rumah yang diperiksa dikali $100 \%$. Dari hasil perhitungan tersebut diperoleh angka bebas jentik $92,86 \%$, hal ini kurang dari angka standart yaitu $\geq 95 \%$, sehingga angka bebas jentik dinyatakan buruk. Angka bebas jentik dan house index lebih menggambarkan luasnya penyebaran nyamuk di suatu wilayah. Tidak ada teori yang pasti berapa angka bebas jentik dan house index yang dipakai standart, hanya berdasarkan kesepakatan, disepakati house index minimal $5 \%$ yang berarti persentase rumah yang diperiksa jentiknya positip tidak boleh melebihi $5 \%$ atau $95 \%$ rumah yang diperiksa jentiknya harus negative (Widya Hary Cahyati, 2006).

TABEL 3: DISTRIBUSI RESPONDEN BERDASARKAN OBSERVASI PEMBERANTASAN SARANG NYAMUK(PSN) DENGAN KEJADIAN DEMAM BERDARAH DENGUEDI KELURAHAN MANISREJO KECAMATAN TAMAN KOTA MADIUN TAHUN 2015

\begin{tabular}{|c|c|c|c|}
\hline \multirow{2}{*}{ PSN } & \multicolumn{2}{|c|}{ Kejadian Demam Berdarah Dengue } & \multirow{2}{*}{ Jumlah } \\
\cline { 2 - 3 } & Sakit & Tidak Sakit & \\
\hline \multirow{2}{*}{ Baik } & 35 & 5 & 40 \\
\hline \multirow{2}{*}{ Buruk } & $(35,72 \%)$ & $(5,1 \%)$ & $(40,82 \%)$ \\
\hline \multicolumn{2}{r|}{ Total } & 5 & 58 \\
& $(53,08 \%)$ & $(5,1 \%)$ & $98(100 \%)$ \\
\hline
\end{tabular}

Sumber: Data Hasil Survey di Kelurahan Manisrejo Kec. Taman Bulan Maret Tahun 2015

Berdasarkan data hasilsurvey pemberantasan sarang nyamuk dengan kejadian demam berdarah dengue dinyatakan kategori pemberantasan sarang nyamuk buruk dengan yang sakit yaitu 53 orang dengan presentase $54,08 \%$ dan yang tidak sakit yaitu 5 orang dengan presentase $5,1 \%$, jumlah presentase yaitu $59,18 \%$. Sementara kategori pemberantasan sarang nyamuk baik dengan yang sakit yaitu 35 orang dengan presentase $35,72 \%$ dan yang tidak sakit 5 orang dengan presentase $5,1 \%$, jumlah persentase buruk yaitu 40,82\%. Sasaran PSN demam berdarah yang paling diprioritaskan adalah di wilayah kecamatan endemis dan sporadic demam beradarah agar semua keluarga dan pengelola

3. Kejadian DBD dan Keadaan Sosial-Ekonomi Masyarakat.

TABEL 4: DISTRIBUSI RESPONDEN BERDASARKAN OBSERVASI SOSIAL EKONOMI DAN KEJADIAN DEMAM BERDARAH DENGUEDI KELURAHAN MANISREJO KECAMATAN TAMAN KOTA MADIUN TAHUN 2015

\begin{tabular}{|c|c|c|c|}
\hline \multirow{2}{*}{ Sosial Ekonomi } & Kejadian Penyakit Demam Berdarah Dengue & \multirow{2}{*}{ Jumlah } \\
\cline { 2 - 3 } & Sakit & Tidak Sakit & \\
\hline \multirow{2}{*}{ KK Tidak Miskin } & 87 & 2 & 89 \\
\hline \multirow{2}{*}{ KK Miskin } & $(85,71 \%)$ & $(5,10)$ & $(90,81 \%)$ \\
\hline \multicolumn{2}{|c|}{$(1 \%)$} & $(9,9 \%)$ \\
\hline
\end{tabular}

Sumber: Data Hasil Survey di Kelurahan Manisrejo Kec. Taman Bulan Maret Tahun 2015 tempat-tempat umum melaksanakan PSN demam berdarah serta menjaga kebersihan di lingkungan masing-masing, sehingga bebas jentik nyamuk Aedesa egypti (Kementrian Kesehatan Republik Indonesia Direktoral Jenderal, 2011)

Suksesnya gerakan ini diperlukan sosialisasi kepada masyarakat/individu untuk melakukan kegiatan ini secara rutin serta penguatan peran tokoh masyarakat untuk mau secara terus menerus menggerakkan masyarakat harus dilakukan melalui kegiatan promosi kesehatan, penyuluhan di media masa, serta reward bagi yang berhasil melaksanakannya (Kementrian Kesehatan Republik Indonesia Direktoral Jenderal, 2011). 
Berdasarkan data di atas hasil survey sosial ekonomi dengan kejadian demam berdarah dengue dinyatakan kategori soaial ekonomi KK miskin dengan yang sakit yaitu 1 orang dengan presentase $1,02 \%$ dan yang tidak sakit yaitu 8 orang dengan presentase $8,88 \%$, jumlah presentase kategori observasi sosial ekonomi yaitu 9,9\%. Sementara katgori KK tidak miskin yang sakit yaitu 87 orang dan yang tidak sakit 2 orang dengan presentase kategori perilaku buruk yaitu $90,81 \%$. Konsep sehat dan sakit menjadi mantap yang mempengaruhi persepsi/ pandangan cara hidup dan upaya seseorang untuk dapat meningkatkan derajat kesehatannya. Dengan demikian pemberantasan Aedes dirasakan sebagai suatu kebutuhan yang dilestarikan hasilnya sehingga upaya untuk menyehatkan diri dan lingkungannya akan mereka laksanakan secara spontan. Hal ini akan menjadi suatu kebiasaan, sikap dan perilaku seseorang untuk hidup sehat. Pendidikan kesehatan tidak dapat diberikan kepada seseorang oleh orang lain, bukan seperangkat prosedur yang harus dilaksanakan atau suatu produk yang harus dicapai, tetapi sesungguhnya merupakan suatu proses perkembangan yang berubah secara dinamis, yang di dalamnya seseorang menerima atau menolak informasi, sikap, maupun praktek baru, yang berhubungan dengan tujuan hidup sehat (Suwarono Edi, 2010)

\section{KESIMPULAN}

Berdasarkan hasil penelitian maka dapat disimpulkan sebagai berikut:

1. Hasil survey pelayanan kesehatan masyarakat paling besar masyarakat ketika terkena DBD berobat ke puskesmas sebesar $66,3 \%$.

2. Distribusi responden berdasarkan perilaku dan kejadian demam berdarah Dengue kategori perilaku buruk dengan yang sakit yaitu 81 orang dan yang tidak sakit 5 orang dengan presentase kategori perilaku buruk yaitu $87,75 \%$.

3. Distribusi rumah responden berdasarkan suhu dan kelembaban dengan kejadian demam berdarah Denguedinyatakan kategori suhu dan kelembaban optimum dengan yang sakit yaitu 72 orang dan yang tidak sakit yaitu 10 orang dengan presentase kategori rumah penderita berdasarkan suhu dan kelembaban tidak optimum yaitu $83,67 \%$. Ini menunjukkan bahwa penderita demam berdarah Dengue paling besar mempunyai rumah dengan suhu dan kelembaban optimumuntuk perkembangbiakan nyamuk Aedes aegypti.

4. Distribusi rumah responden berdasarkan angka bebas jentik kategori angka negatif jentik dengan yang sakit yaitu 82 orang dan yang tidak sakit 9 orang dengan presentase yaitu $92,86 \%$. Ini menunjukkan bahwa kelurahan Manisrejo belum terbebas dari jentik.

5. Distribusi responden berdasarkan pemberantasan sarang nyamuk dengan kejadian demam berdarah Dengue dinyatakan kategori pemberantasan sarang nyamuk buruk dengan yang sakit yaitu 53 orang dan yang tidak sakit yaitu 5 orang dengan presentase yaitu $59,18 \%$. Sementara kategori pemberantasan sarang nyamuk baik dengan yang sakit yaitu 35 orang dan yang tidak sakit 5 orang dengan presentase yaitu 40,82\%. Ini menunjukkan bahwa penderita demam berdarah Dengue paling besar mempunyai pemberantasan sarang nyamuk yang buruk.

6. Distribusi responden berdasarkan sosial ekonomi dengan kejadian demam berdarah Dengue dinyatakan kategori soaial ekonomi kk miskin dengan yang sakit yaitu 1 orang dan yang tidak sakit yaitu 9 orang dengan presentase kategori angka positif jentik yaitu 9,9\%. Sementara kategori pelayanan kesehatan berobat ke rumah sakit dengan yang sakit yaitu 87 orang dan yang tidak sakit 2 orang dengan presentase kategori perilaku buruk yaitu $90,81 \%$. Ini menunjukkan bahwa demam berdarah Dengue paling besar diderita oleh kk tidak miskin.

\section{SARAN}

1. Perlu dilakukan peningkatan pengetahuandan

penggerakanmasyarakat khususnya mengenai penyakit $\mathrm{DBD}$, dengan cara penyuluhan, sehingga masyarakat dapat paham dan mengerti mengenai penyakit DBD.

2. Perlu diiadakan pemeriksaan oleh jumantik setiap bulannya sehingga dapat digunakan untuk memantau pertumbuhan jentik nyamuk, sehingga kejadian DBD dapat ditekan serendah mungkin.

3. Masyarakat perlu diberikan pengarahan mengenai PSN (Pemberantasan Sarang 
Nyamuk) sehingga masyarakat mengetahui apa saja program-program dari pemberantasan sarang nyamuk sehingga masyarakat dapat ikut serta dan berperan dalam pemberantasan sarang nyamuk itu sendiri.

4. Masyarakat perlu memperhatikan kondisi lingkungan seperti membuka jendela atau ventilasi, hal ini dapat membantu mengurangi suhu dan kelembaban, dikarenakan suhu dan kelembaban berpengaruh terhadap daya hidup nyamuk.

5. Faktor sosial ekonomi dan pelayanan kesehatan juga perlu diperhatikan dalam pemberantasan sarang nyamuk, agar pemberantasan sarang nyamuk dapat berjalan dengan baik.

6. Perlu dilakukan penelitian lebih lanjut terhadap variable PSN, perilaku, suhu dan kelembaban, angka bebas jentik dengan kejadian demam berdarah Dengue.

\section{DAFTAR PUSTAKA}

Edi Suwasono, 2010. Pedoman Kesehatan Masyarakat. Jakarta Barat.CV.Pamularsih.

Diklat Jabatan Fungsional Entomolog Kesehatan di BBPK Ciloto, 2008.

Isman Amin, 2009. Statistika praktisi kesehatan. Yogyakarta. Graha ilmu.

Pallutturi, Sukri. 2005. Ekonomi Kesehatan. Penerbit : Bagian Administrasi dan Kebijakan Kesehatan FKM UNHAS

Sjamsunir Adam, $1982 . \quad$ Pelajaran pemeliharaan kesehatan masyarakat. Jakarta. Bhintara karya aksara.

Sugiyono, 2013. Metode penelitian kuantitatif kualitatif $R$ dan $D$. Bandung.Alfabeta Rajawali Press

Teguh Widiyanto, 2007. Kajian Manajemen Lingkungan Terhadap Kejadian Demam Berdarah Dengue (DBD) di Kota Purwokerto Jawa Tengah .Program Pasca Sarjana Universitas Diponegoro Semarang. Semarang. 